\title{
Nationalism and Democracy. Manuel Irujo Ollo: The Leadership of a Heterodox Basque Nationalist
}

\author{
LUDGER MEES \\ UPV/EHU, University of the Basque Country
}

\begin{abstract}
Manuel Irujo Ollo was one of the most prominent leaders of moderate Basque nationalism. Irujo, who was born in 1891 and died in 1981 at the age of 89, had a Basque, Spanish, and European dimension to his political career, which was perhaps the most enduring and intensive of any leader to emerge during the entire history of this socio-political movement. Yet Irujo's political life remains largely quite unknown: no comprehensive academic biography has been written on his political work. Obviously, this article does not pretend to fill this void. Instead, it aims to cast a light on the nationalist leader's political life from the twofold perspective of his individual political activity and the lessons that can be learned for a broader understanding of Basque nationalism in particular and of the relationship between nationalism and democracy in general.
\end{abstract}

\section{Resumen}

Manuel Irujo Ollo fue uno de los más significativos líderes del nacionalismo vasco moderado. En la historia de este movimiento socio-político probablemente no existe otro líder con una trayectoria política tan duradera e intensa con una dimensión vasca, española y europea como la de Irujo, quien nació en 1891 y murió en 1981 a la edad de 89 . Pese a ello, hoy día la vida política de Irujo sigue siendo en buena parte desconocida, puesto que hasta la fecha no existe una biografía completa escrita con rigor científico. Obviamente, este artículo no pretende subsanar este déficit, pero sí aspira a arrojar luz sobre la biografía política del líder nacionalista desde una doble perspectiva: no sólo se analizará su actividad política individual, sino que también se preguntará sobre las conclusiones que se pueden extraer de este análisis para la historia del nacionalismo vasco y, más en general, sobre la relación entre nacionalismo y democracia. 
El suaviter in modo fortiter in re debe ser compañero de nuestras actividades [...]. Guardemos nuestro puesto; creemos cada día; seamos tolerantes con las ideas de los demás, aunque ellos no lo sean con nosotros. Algún día nos encontraremos con el fruto sazonado de nuestra conducta.

Manuel Irujo Ollo (1953)

I

The idea of the nation has probably been the most powerful agent of popular mobilization during the last two centuries. ${ }^{1}$ With the possible exception of religion, there is no other idea in history whose defence has provoked more deaths than that of the nation or the fatherland. In all crucial historical situations it has proved to be more powerful than its most serious rival: the idea of class solidarity across national boundaries. One of the most fatal examples of this domination has been very recently highlighted once again by historians who attempted to recover the memory of World War I, a hundred years after its outbreak. ${ }^{2}$ In 1914, all European socialist parties, with very few individual exceptions, succumbed to nationalist euphoria, decided to back their governments' military strategies and completely abandoned the discourse of international class solidarity. The collapse of the Second International, the supranational organization of socialist and labour parties, was the logical consequence of the nationalist tsunami that devastated Europe between 1914 and 1918.

Still, the idea of the nation not only nourished imperialist and, later, fascist discourses and policies but it would also appear on the opposite side of imperialism when acting as an ally of liberalism and democracy. More than this: the idea of the nation was born as a powerful weapon in the struggle against the absolutist elites of the ancien régime, because it rejected the traditional legitimation of power by heritage and divine mandate while demanding the establishment of a new political system according to the principle of national sovereignty, constitutional rights and parliamentary pluralism. Thus, historically nationalism served for both the consolidation and the dismantling of democracy.

This contradictory and Janus-faced reality of nationalism can be found in the history of nearly all nationalist movements. The history of Basque nationalism is no exception. It was born at the end of the nineteenth century as a petitbourgeois radical protest movement for Basque self-determination and based on an ethnicist and racial concept of nation, which excluded all non-native immigrant workers from the Basque nation. ${ }^{3}$ Being initially anti-liberal and partly xenophobic, over time Basque nationalism evolved, abandoned its most controversial and radical characteristics and became a democratic movement

1 This article is a result of a broader research project carried out thanks to the support provided by the University of the Basque Country (GIU 14/30), the Spanish Ministry of Economy and Competitiveness (HAR2015-64920-P) and the European Regional Development Fund.

2 See MacMillan 2013; Clark 2013; McMeekin 2013; Münckler 2013.

3 See Larronde 1977; Corcuera 2001; Elorza 2001; Pablo, Mees and Rodríguez Ranz 1999. 
with an active participation in the struggle for the democratization of the corrupt political system of the Restoration Monarchy. Although it might seem a contradiction, it can be concluded that Basque nationalism, together with the other great new political movement of the end of the nineteenth century, Spanish socialism, was one of the most important democratic 'modernizers' in Spanish politics in so far as it helped to overcome the traditional understanding of politics as a realm of a small power elite and substitute this concept with the more democratic idea of politics as a concern of common people.

As a consequence of this evolution, in 1936 the Partido Nacionalista Vasco (PNV), decided to join the Spanish democrats in their fight against the (Spanish nationalist) rightist generals and their putsch against the Second Republic (Pablo, Mees and Rodríguez Ranz 2001; Granja 2007). After the collapse of the Republic and the establishment of the Francoist dictatorship, the Basque government in exile continued this fight for democracy in a new context. So did, at least initially, the radical nationalist underground organization ETA, which was founded in 1959 with the goal of overthrowing the Francoist regime and establishing Basque independence. Yet the organization's evolution towards Marxism-Leninism and the armed struggle at the end of the 1960s supposed a radical break with the Basque government's liberal concept of democracy and freedom. So once again, the history of ETA became another example of the inherent contradictions of the national idea. During the last years of Francoism, the group's violent blows against the regime and its representatives generated the aura of a courageous fight against the almighty dictatorship and for democracy, which was also, if not applauded, then at least accepted and legitimated by many Basque and Spanish non-nationalists. After Franco's death in 1975 , however, when the channels for legal political participation were opened and Basque autonomy restored, ETA ended up as a totalitarian and Mafia-like terrorist group waging a bloody war not against dictatorship, but against the national enemy: the Spanish state. Anybody who dared to oppose ETA's discourse and military strategy towards national liberation was likely to be considered a collaborator with the enemy in its eyes and, in consequence, become another target to add to the long list of the group's victims, which include more than 800 assassinated people and destroyed families (Jáuregui 1985; Elorza 2006). This was the end of a long historical cycle.

Even though ETA's idea of the nation never really was liberal, pluralistic and democratic, in the context of dictatorship people perceived it as a nationalist freedom fighter. During the Transition and the first years of democracy, which was the bloodiest period in ETA's history, the underground group still benefited from this accumulated political capital and its image as a selfless rebel against the dictatorship and for Basque freedom. At the end, nothing of this political capital remained and the popular perception changed completely. In the eyes of most people it was now looked upon as a radical terrorist group that handled the idea of the nation not to fight for freedom but to undermine democracy and establish a new dictatorship based on violence and exclusion. 
This complexity of nationalism, with its inherent contradictions, is one of the reasons that has complicated - and continues to complicate - the scholarly analysis of the phenomenon. This difficulty is also due to the fact that nationalism is far more than a historical fact. It is also a current political and social reality that continues generating news, passion and polemics. During the last few decades, historians have tried different methodological approaches to resolve this problem of complexity and the influence of passion when tackling the analysis of nationalism. One of those approaches, and the one chosen for this article, is the biographical one. The long political biography of the Basque nationalist leader Manuel Irujo Ollo forms an appropriate analytical field for the investigation of Basque nationalism, its relationship with democracy and its internal contradictions. Yet the biographical approach itself is not unquestioned and presents several problems and risks that should be spelled out before continuing with a more detailed analysis of Manuel Irujo's political biography.

\section{II}

First of all, it is no exaggeration to state that when a historian is asked to write or talk about an important historical personality and to analyse his or her political biography, that historian should be glad because, as is well known, the biographical approach has become the methodology with the most popular impact in the area of historiography (Burdiel 2000; Caine 2010; Rotberg 2010). Since the famous cultural turn and its criticisms against what many scholars linked to this epistemological proposal considered the excesses of the structuralist paradigm, historians and other social scientists have rediscovered human agency, freeing the individual and collective creativity of the human being from his or her particular prison. According to the structuralist point of view, which was now submitted to the culturalists' criticism, this was a prison made of the almighty structural context against which the human being might stand and rebel, only to ultimately learn once again the lesson of his or her impotence.

Even if this criticism against the structuralist approach has been exaggerated in many cases and is not always justified, the fact is that it has facilitated a certain reshaping of historical thought, by which the human being, as an individual and as a collective, has been brought back into historical focus. Thanks to this evolution, a new and better equilibrium between the individual's singularity, on the one hand, and the broader structural context in which human agency has to act, on the other, emerged. Now it should be easier to put into praxis the famous sentence written by one of the most outstanding theorists of structuralism: Karl Marx, who in his The Eighteenth Brumaire of Louis Napoleon made the famous statement that 'men make their own history, but they do not make it as they please; they do not make it under self-selected circumstances, but under circumstances existing already, given and transmitted from the past' (Marx 1999, 1: 1).

Yet if we analyse the wave of biographies that have been published during the last two decades, it becomes evident that many of those books have not really 
found their way towards this equilibrium between personality and structure mentioned by the young Karl Marx. They did not manage to do it, because their authors were not able to escape the two temptations that every biographer has to confront. In his essay titled Sketches from Life, Patrick K. O'Brien puts it this way: 'political biographers succumb all too often to one or the other (and sometimes to both) of two temptations: either they present their subjects as extraordinary and omnipotent, or alternatively, as predictable individuals whose characteristics and actions form the basis for generalizations about the governments of the day' (O’Brien 1998: 50).

The best way of escaping from these temptations while defending the biographical approach as a methodological tool to learn something about the complex relationship between structure and agency is to be aware of them. Yet, O'Brien's warning about the errors that a biographer should not commit must be handled with caution and flexibility during the process of historical research, since - as we shall see - what the author considers an 'error' might turn out to be a historical reality. Thus, as I will try to explain in this article, I would indeed support the view that Manuel Irujo was an extraordinary leader, even though he was not at all omnipotent; and second, I would also defend the thesis that the study of Irujo's characteristics and actions help us to discover important insights into the general history, in this case not of the government but of Basque nationalism and, especially, of the Basque Nationalist Party founded by Sabino Arana Goiri in 1895. Nonetheless, even if it is true that Irujo's activity permits broader comparisons and generalizations, this activity was never really completely predictable, because his personality was too complex to permit any kind of easy prediction. As we shall see, Irujo was always a nonconformist, free spirit who, despite his loyalty to certain values, thoughts and organizations, on many occasions of his life preferred being an outsider to running with the mainstream or to submitting to authority simply because it was authority.

Based upon these general considerations, and rather than go into all the details of Irujo's long and rich political biography, I would like to outline some ideas with the aim of explaining the points I have just mentioned. Thus, I shall first try to explain why I consider Irujo to be an extraordinary leader and what his relationship as a Basque nationalist was to democracy. I shall then ask to what extent his biography as a nationalist leader was typical of Basque nationalism and to what extent it was particular and unique.

III

To begin with, the case of Irujo is a special case from a biographical point of view: Irujo's political career was perhaps the most enduring and intensive of any leader to emerge during the entire history of this socio-political movement. ${ }^{4} \mathrm{He}$

4 Surprising as it might be, there is not one single academic biography on the political life of Manuel Irujo. The books of Ibarzabal (1977), Ugalde (1992) and Amezaga (1999) are, rather, personal and journalistic accounts, yet they provide some interesting informa- 
was born in 1891 in Estella/ Lizarra and died in 1981 at the age of 89. He grew up in a very nationalist milieu in Navarre and his family was one of the most important cells for the spread of Basque nationalism in the province. Manuel's father was a nationalist pioneer who served as a lawyer to the party's founder Sabino Arana in various trials between 1895 and 1902. Manuel's cousin, another Manuel (Aranzadi), became a deputy in the Spanish Parliament during the Restoration Monarchy. Three out of his seven brothers also became members of the PNV, and another two joined the liberal and republican nationalist Acción Nacionalista Vasca founded in 1930. Manuel Irujo was himself affiliated to the PNV in 1908, at the age of seventeen. The PNV remained his party until his death, despite his quite frequent disagreements and conflicts with the party's leadership.

Although a prominent nationalist leader, Manuel Irujo was unlike other leaders in the party because he never held a high-ranking position within the PNV's hierarchy, whether in Navarre or in the EBB, the national directive council of the PNV. Instead, he dedicated a good part of his political activities to representing the party in different public institutions. There was probably no other nationalist leader with such an all-round presence in all kinds of public offices during the twentieth century. He started his career during the Restoration Monarchy as a deputy in the regional government of Navarre; when the Republic was established he became a deputy in the Spanish Parliament representing the province of Guipúzcoa; during the Civil War he was a minister in the Spanish Republican governments headed first by Francisco Largo Caballero and then by Juan Negrín. When World War II began, he served as the President of the National Council of Euzkadi in London due to the forced absence of the Lehendakari Aguirre (Jiménez de Aberásturi 1987). Between 1945 and 1947 he returned as a minister to the Spanish republican government in exile under José Giral and Rodolfo Llopis; after its foundation in 1949, he became the Vice President of the Spanish Federal Council of the European Movement and, in 1973, its President; at the end of his life, during the Transition to democracy, Irujo was a senator for Navarre and, once again, a deputy in the regional parliament of Navarre.

This list does not need any further comment. It speaks for itself and provides evidence for one of the main features of Irujo's biography: his almost neurotic, unstoppable need to be active and to intervene in the course of history. He needed to be present and engaged in all matters because he believed deeply in several values and political credos, and these beliefs were not at all a private issue for Irujo. On the contrary, they were a rather permanent invitation to fight for these ideals, to defend their necessity, to win over public opinion and to implement them in the institutional arena. What were these ideals, values and credos? If we tried to summarize them, the list would be as follows: Irujo was a Basque nationalist very close to the idiosyncrasy and interests of his much beloved homeland of Navarre. He was a strong defender of Basque autonomy

tion. Vignaux (1986) refers exclusively to Irujo as minister during the Civil War. The only academic approaches can be found in the monographic issue of the review Vasconia (2002), and in Mees and de la Granja (2012). 
and a Catholic who was very preoccupied with the problems of social justice. He was a defender of the Spanish federal republic and a fighter against Francoism, who in return was forced into a long exile of nearly four decades. Moreover, and according to his Christian humanism, Irujo was attached to the European Christian Democratic movement, as well as to European federalism. Finally, Manuel Irujo was a person who believed in the importance of culture and education. He graduated in Philosophy and Literature (Filosofía y Letras) from the Jesuit University of Deusto, where he also received a law degree in 1912. Due to his unlimited hunger for knowledge, Irujo was also a tireless reader and writer. When he was not working on one of the several books he published during his life, or redacting one of his never-ending letters - many containing fifteen or twenty pages - he passed many hours reading any kind of publication, preferably books on history. The rich personal library, which was very recently donated to the University of Liverpool, is a good example of this passion for knowledge. Irujo did not want to keep this knowledge for himself. Instead, as an active member of the Society for Basque Studies, or Eusko Ikaskuntza, he was keen to deliver his knowledge and wisdom to others.

Manuel Irujo was also a very special personality in the history of Basque nationalism in another sense: he was the closest person to the most important, influential and popular Basque nationalist leader of the twentieth century. As Irujo himself confessed in one of his articles, José Antonio Aguirre, the first Basque President or Lehendakari, was his 'best friend' (Irujo 1960: 157). ${ }^{5}$ This close relationship grew slowly over the course of the Second Republic when Aguirre became the supreme leader of the movement for Basque autonomy. During the long and hard years of exile, their friendship became even stronger and more intensive both politically and personally. When the Francoist troops were about to conquer Catalonia and expel the Catalan and Basque governments from Barcelona and into French exile, Irujo did not hesitate to join Lehendakari Aguirre on his way back from Paris to the Catalan front. In a gesture of solidarity, Aguirre had promised the Catalan President, Lluís Companys, that he would accompany him should he be forced to leave his fatherland. Aguirre also thought that it was his duty to be together with the staff of his government, which in October 1937 was located in Barcelona, during those painful moments of defeat. During the last dinner at Aguirre's residence in Paris before the departure to Catalonia, Irujo tried to be as relaxed as possible, joking and cheering up his President. But he was well aware of the danger that this gesture of solidarity supposed for both of them. He was not sure that he and Aguirre would ever return from that trip. As he wrote in a letter to the priest Alberto Onaindia, he did not wish to be a hero and die as 'cannon fodder'. ${ }^{6}$ In the end, both men survived, returned to

5 See Elías Amezaga 1988; Mees 2006 and 2012; Mees et al. 2014.

6 Irujo added: 'Prefiero que no me maten. Aunque sea el último, querría salir de la frontera de España, para donde saldré mañana'. Onaindia described the dramatic atmosphere during that dinner of farewell and Irujo's intervention with these words: 'El día 24 ceno con el Presidente y con Irujo, momentos antes de partir los dos para Catalunya. Al Presidente le noto muy pensativo, y durante toda la cena se dedica a estar con sus dos niños. 
France and entered into a lifelong friendship replete with moments of disagreement, mutual recrimination and political clashes that had to be surmounted, as we shall see later.

But in addition to this very close relationship to Lehendakari Aguirre - who used to have dinner at his private residence in Paris nearly every Saturday with Onaindia and Irujo - I would like to highlight one more special feature in Irujo's long political life. Therefore we have to return to the outbreak of the Civil War and recall the political context in which this coup d'état was perceived by the PNV leadership. The party's leadership was caught off guard when news of the military uprising arrived in the days following 17 July 1936. There were essentially two problems that made an immediate reaction difficult. First, and despite the shift from the political right to the centre that the PNV had carried out during the last two years of the Republic (executed by the new generation of more liberal and open-minded leaders like Aguirre and Irujo), the PNV was still a very Catholic political party, obedient to the ecclesiastical hierarchy and the Vatican. During the first two years of the Republic, the anti-clerical policy of the centre left government had poisoned the relationship with the PNV and the parties of the right. Moreover, in 1931 the PNV had established an electoral alliance with the Carlists, which was the greatest political enemy of the new Republic on the extreme right. It was not until 1934, when a period of crude confrontation between the PNV and the new centre right republican government began, that this absolute mutual lack of confidence was corrected little by little (Granja 2008). Nonetheless, when the leftist Popular Front won the elections of February 1936, fear of a new wave of radical anticlericalism grew among many Basque nationalists. If the demand for regional autonomy brought the PNV nearer to the left, then the issue of religion was an ideological bridge to the political right. Consequently, since one of the most powerful arguments used to legitimize the military insurrection was the defence of religion, it is understandable that the PNV felt torn when news arrived of the fascist coup against the leftist government.

But a second problem complicated the situation even further. Since the party's foundation in 1895, there had been a strong school of political thought within its ranks that considered everything that happened beyond the Basque borders as irrelevant to the Basque nation. Any deal with Spanish politicians, or participation in Spanish institutions, was rejected as a betrayal of Basque national interests and, furthermore, as a permanent source of exotic contamination. This is why the PNV's first serious participation in the elections to the Spanish parliament did not take place until 1918. According to this traditional pattern of behaviour, later, in 1930-1931, with Basque nationalism completely absorbed by

Tenía que partir, y con una serenidad admirable, cuando su señora le despedía llorando, le dijo: "No te apures. Voy a cumplir con mi deber, y esto te debe de alegrar". Al salir, en la puerta, le dijo Irujo: "Mira, si tu mujer no lloraría [sic], no sería tu mujer. Esa es la intimidad de la familia, y tu sacrificio así es mayor"'. See the report 'Informe sobre la partida de José Antonio Aguirre a Catalunya', 24-I-1939, Archivo del Nacionalismo, Fondo Alberto Onaindia. 
the effort of unifying the party that had split in 1921, the official position in the dispute between monarchy and the Republic was non-involvement.

In July 1936 similar doubts surfaced: Was the military coup relevant to Basque interests? Would the most sensible attitude be that of strict neutrality? Manuel Irujo was one of the very few leaders who did not spend a single minute with these kinds of doubts. From the very beginning, he was absolutely aware that the insurrection, especially for the Basques, was a question of life and death and that therefore an attitude of isolation or neutrality was completely impossible. After receiving the news of the rightist uprising and its easy victory in Navarre and most parts of Alava, the deputies Manuel Irujo and José María Lasarte proclaimed a manifesto over local radio in Guipúzcoa stating that 'sea cual sea el objetivo perseguido por los sublevados' the PNVwould defend 'la encarnación legítima de la soberanía popular representada en la República' (Pablo, Mees and Rodríguez Ranz 2001: 10). This manifesto was issued without any consultation with the PNV leadership (EBB), which, at a meeting in San Sebastian the very same day, 18 July, overruled the communiqué of Irujo and Lasarte and agreed upon a new statement defending the party's neutrality in the conflict.

This statement was delivered to the director of the nationalist daily in San Sebastian, El Día, for its publication the next day. However, before this new official communiqué could be printed, the insurrection and the first armed confrontations spread to San Sebastian. In this new context, and after consulting with Irujo, the director of the daily decided that the party's neutrality was no longer possible and opted not to publish the communiqué, whose exact wording is not known. A day later, after having analysed the rapidly evolving situation, the PNV leadership, now in Bilbao, reached the same conclusion and issued a new declaration to the nationalist daily Euzkadi, this time with a clear statement in favour of the defence of the Republic. Juan Ajuriaguerra, the leader of the PNV in Vizcaya, described the dilemma of his colleagues on the PNV's governing board who preferred not to take a clear stance in favour of one side or the other. Eventually, all of them agreed to issue another communiqué that strongly supported the Republic against fascism, even if this decision, in the words of Ajuriaguerra, was taken 'sin mucho entusiasmo, pero convencidos de haber elegido el bando más favorable para los intereses del pueblo vasco'.?

7 Ajuriaguerra's important testimony about the process of decision making within the PNV leadership during the crucial hours following the coup d'état reads in the Spanish original like this: 'Tenía la esperanza de escuchar alguna noticia que nos ahorrase el tener que tomar una decisión: que uno u otro bando ya hubiese ganado la partida. A medida que avanzaba la noche, algo iba quedando bien claro: el alzamiento militar lo había organizado la oligarquía derechista cuyo eslogan era la unidad, una agresiva unidad española apuntada hacia nosotros. La derecha se oponía ferozmente a cualquier estatuto de autonomía para el País Vasco. Por otro lado, el gobierno legal nos lo había prometido y sabíamos que acabaríamos consiguiéndolo. A las seis de la mañana, tras una noche en blanco, tomamos una decisión unánime. Promulgamos una declaración dando nuestro apoyo al gobierno republicano. Tomamos esa decisión sin mucho entusiasmo, pero convencidos de haber elegido el bando más favorable para los intereses del pueblo vasco; convencidos también de que, de habernos decidido por el otro bando, nuestra base se nos hubiera opuesto' (qtd. in Fraser 1979: 66). 
As we can see, the party needed one entire day to reach the conclusion Irujo had put forward on 18 July and which had been disallowed by the EBB only a few hours before. In these crucial and dramatic moments in the history of the Basque Country, the Navarrese leader provided another example of his political intelligence, and he was able to do so long before the PNV leadership because he managed to see very clearly what was actually at stake: that was neither the question of religion nor the dispute about Basque versus Spanish interests, but rather the very survival of democracy and human rights. Or, to put it somewhat more provocatively: Irujo was able to act and decide in this way because in this crucial moment of crisis he gave priority to his thinking and feeling as a democrat, forgetting for a moment the bad experience of anticlericalism and clashes with the republican left that he had suffered as a Catholic nationalist (Granja 2007: 293-348; Pablo, Mees and Rodríguez Ranz 2001: 9-15).

Manuel Irujo was not only a pioneer of the PNV's political and military commitment against fascism and in favour of democracy but he was also a pioneer in other important areas. Together with his friend and President, José Antonio Aguirre, Irujo was one of the first prominent Basque leaders who tried to update the nationalist platform in light of the new experience of growing European unification. As the significance of the nineteenth-century notion of national sovereignty eroded he did not really develop a new theory concerning the problem of bringing together the demand for Basque self-determination and the reality of a continent in which the economy, markets and politics were becoming evermore interrelated. Yet his conclusion was very clear when he wrote about this problem, for instance in the Mexican Euzko Deya in 1959: 'El antiguo concepto de "independencia" ha evolucionado, porque hoy no es posible que pueda darse la independencia absoluta de ningún país; por grande y poderoso que sea' (Irujo 1959). As a consequence, in a very interesting polemic with the PNV leader Juan Ajuriaguerra, Irujo expressed his completely unorthodox conviction that the best way for the Basque Country to enter Europe was by being part of the Spanish state. Ajuriaguerra's response was extremely withering: he held that somebody who posited such ideas simply was no Basque nationalist. From that point on, and due to this kind of unorthodox and fearless reasoning, Irujo became a very respected person within Basque nationalism, even if for many members of the PNV he was also a kind of rara avis who had become contaminated by his close and daily relations with Spanish politics. The following recommendation by Ajuriaguerra in a letter to his colleagues on the PNV's board of directors is very telling in this sense:

Tiene que ser muy difícil sujetarle a Manuel, que no sabe estar inactivo y cuya cabeza siempre está en efervescencia. El único procedimiento para sujetarle sería el encomendarle algo que dé salida a su actividad por otros caminos y que le obligara a separarse de las tertulias españolas que frecuenta, donde se habla mucho, aunque los demás se contenten con eso y él no. ${ }^{8}$

8 Ajuriaguerra's letter written under the pseudonym 'Xabier' to the PNV leadership in exile ['Dionisio'], 20 September 1947, Archivo del Nacionalismo, K 217, C 1. 
Fortunately, I would say, during the rest of his life nobody really managed to make such an offer to Irujo, who remained the same unorthodox and openminded nationalist as ever before.

But there is still a final point that has to be mentioned in this brief list of themes or issues in which Irujo can be considered a very special nationalist leader with the qualities of an authentic pioneer. I mean the question of political violence. It is well known that in 1959 the PNV suffered what was probably the most dramatic split in the party's history after the foundation of the underground group ETA. Under the influence of Marxist-Leninist thought, and inspired by the experience of the anti-colonial liberation movements in the so-called Third World during the 1950s and 1960s, ETA soon abandoned the group's initial loyalty to the Basque government, opting for armed struggle and killing their first victim in 1968. As already mentioned above, during the years of Francoism, and even after Franco's death in 1975, ETA gained a reputation as a group of altruistic freedom fighters and this reputation was common not only among the Basque nationalists but also among other Basque and Spanish democrats. Due to this image, the PNV leadership needed some time to articulate a serious and unambiguous criticism of ETA's armed activity. Moreover, there are examples of PNV leaders, such as the former deputy and councillor in President Aguirre's government, Telesforo Monzón, who abandoned the PNV and joined the nationalist left that was close to ETA (Mees and Casquete 2012). Irujo, once again, displayed a strange capacity to foresee the future and recognize the extremely dangerous dynamic ETA was likely to develop. Thus, as early as autumn of 1962 he had already defined ETA as 'un cáncer que, si no lo extirpamos, alcanzará todo nuestro cuerpo político'. ${ }^{9}$ After Irujo wrote down these words, half a century had to pass until ETA declared in October 2011 the definite, unilateral and unconditional cessation of the group's armed activity. Fifty years and more than 800 fatalities later, one might ask why nobody really listened to the words of Irujo in 1962.

\section{IV}

These are only some of the very special features in the political life of Manuel Irujo, special features that made him a really extraordinary and singular person in the history of Basque nationalism and Basque politics in general. What are the more general lessons we can learn about this history by analysing the biography of this exceptional politician? To what extent was he representative of the PNV's mainstream, rather than an eccentric outsider?

The authors of the book cited on the history of the Basque Nationalist Party described one of the essential features of the party's history using the metaphor of a pendulum (Pablo, Mees and Rodríguez Ranz 1999 and 2001). The argument is that since its foundation until practically nowadays the PNV has moved like a pendulum between two outlooks, one being pragmatism, compromise

9 Letter from Irujo to Jesús Solaun qtd in Pablo, Mees and Rodríguez Ranz 2001: 271. 
and moderate demands for autonomy, and the other essentialism, isolation and radical plans for separation and independence. According to the specific historical context of the moment, the PNV would give priority either to its more moderate or its more radical side. Normally, Manuel Irujo is considered to have been a leader of the more moderate soul of the PNV, but a careful look at his political vita reveals a reality that is far more complex, because it shows us a Manuel Irujo who also lived the swing of the patriotic pendulum within his own biography. Without going into details, here are just a couple of hints as to how that is the case. In the spring and summer of 1931, like the rest of the party's leadership Irujo worked hard on the first draft of a regional Basque autonomy, the so-called Statute of Estella. As a product of the alliance between the PNV and the Carlist extreme right, the draft contained a number of provisions that were completely unacceptable to the left, which was governing in Madrid. Even before the draft was rejected as unconstitutional Irujo was the first nationalist leader who dared to recognize in public that the draft of Estella had no future and that the nationalists had to cooperate with the leftist government and back down on some of their demands - especially in the area of religion - if autonomy was to be achieved (Granja 2007 and 2008).

In 1939, after the end of the Civil War and at the beginning of the long exile, Irujo went along with his colleagues in the PNV leadership, including President Aguirre, as the party shifted anew towards radical nationalism. He backed a request made to the Basque socialists and the other parties with representation in the government in exile to break with their organic relations with their Spanish party counterparts and sign a declaration of exclusive obedience to Basque parties and institutions. This was nothing other than an attempt to force the socialists into the role of an obedient satellite of the PNV (Pablo, Mees and Rodríguez Ranz 2001: 97-104). Irujo not only shared in this radical aggression against the political autonomy of Basque socialism but he also acted according to this new radical strategy. As President of the National Council of Euzkadi in London, and during the absence of Lehendakari Aguirre, Irujo provoked a steady stream of polemics due to his authoritarian leadership, his unwillingness to cooperate with the other political parties in the foundation and the development of the Council, and his attempt to completely sideline the more moderate nationalists like Vice Lehendakari Leizaola, who was still in France.

When Aguirre returned to the political stage after having escaped the Nazis, the president found words of praise, but also of criticism, for the work of his friend. Despite being very cautious and diplomatic with the criticism of his friend Manuel, Irujo launched a counter-attack against Aguirre, branding the president a regionalist and a traitor to the ideals of Sabino Arana. The Lehendakari was able to keep cool and maintain patience with Irujo, instead of breaking with his friend. Thanks to Aguirre's patience and to his numerous gestures of estimation and friendship, Irujo little by little reconsidered his political ideas, eventually leaving behind his period of nationalist radicalism and isolation. The culmination of this evolution took place in the summer of 1945, when Irujo 
became a minister in the Spanish government in exile. For two years, Aguirre and Irujo became key figures of Spanish politics in exile with an enormous influence in the government (Mees 2006: 109-151). Ever since, Irujo was known as the most republican of all Basque nationalists, open to any cooperation with other Spanish democrats against the dictatorship. During the rest of his life, his personal pendulum remained fixed on the side of pragmatism, liberalism and moderate nationalist gradualism. As a result, during the transition to democracy Irujo defended a vote in favour of the new Spanish constitution, against the majority of his party fellows, who opted for abstention in the referendum of 1978 .

\section{V}

Just one year before this debate over the new constitution took place, Manuel Irujo decided to put an end to his long exile. After the death of Franco, he had rejected all the invitations of his friends and fellow party members to return to his homeland, arguing that he would only return if the restoration of democracy in Spain were guaranteed. In March 1977, Irujo considered that this condition was about to be fulfilled. He arrived just in time to be the centre of attention at the National Convention that his party held in Pamplona. It was the first legal National Convention of the PNV since 1933 and on this historic occasion two Basque nationalists from Navarre were the most well-received and applauded persons: Carlos Garaikoetxea, the new PNV leader and future Lehendakari; and, at the age of 85, the political veteran Manuel Irujo. Despite his age, Irujo was apparently not yet too tired to engage in politics. During his final years he was a senator for Navarre, deputy of the regional chamber of that province, President of the Assembly of Basque Parliamentarians and member of the Assembly of Navarrese Parliamentarians. He still had time to celebrate the ratification of the Basque Statute of Autonomy in 1979, to feel once more a deep sadness for the exclusion of Navarre from the Basque Autonomous Community, and to congratulate his friend Garaikoetxea for his nomination as the first Lehendakari of the new fledging democracy.

Some months later, on the first day of the year 1981, and after having reached the age of 89, Irujo died. Ever since, he has been an icon in the history of Basque nationalism and Spanish democracy. According to Carlos Garaikoetxea, Irujo was 'un ejemplo en todo, era la pasión de un ideal, la racionalidad de la política, la tolerancia y la cordialidad que hacía que sus propios adversarios le quisieran' (Mees and Granja 2012: 576-78). The socialist leader Txiki Benegas described Irujo as 'un nacionalista abnegado', his nationalism was never 'intransigente' and always 'negociador'. According to Benegas, Irujo never 'fue enemigo de nadie' (2012: 576-78). And, returning to the thoughts at the beginning of this article, we might add and conclude that Irujo's political biography stands as an example of the progressive and democratic face of nationalism. Irujo was a Basque nationalist, but for him the freedom of his nation was unthinkable 
without democracy, humanistic values and human rights. His unique biography is part of Basque, Spanish and European history, but it should also be a guideline for the future. The current crisis of political systems all over Europe is probably the most powerful argument that can be made for why Manuel Irujo's ability to transcend political ideology in search of the greater good should be studied in more detail. To overcome this crisis, ethics have to be reintroduced into politics and political leadership must be freed from the unconditional and unreflected subordination to the decisions taken by the party's hierarchy. In this sense, the memory of Manuel Irujo as a Basque nationalist and as a democratic, unorthodox, and open-minded esprit libre serves to teach us about the past, but it also presents us with an instructive precedent to deal with the challenges of the future.

\section{Works Cited}

Amezaga, Aranzazu, 1999. Manuel Irujo. Un hombre vasco (Bilbao: Fundación Sabino Arana).

Amezaga, Elías, 1988. El primer Aguirre. 4 vols. (Bilbao: Idatz Ekintza).

Burdiel, Isabel, 2000. 'La dama de blanco: Notas sobre la biografía histórica', in Pérez Ledesma, Manuel Burdiel and Isabel Burdiel (eds), Liberales, agitadores y conspiradores. Biografías heterodoxas del siglo XIX (Madrid: Espasa-Calpe), pp. 17-48.

Caine, Barbara, 2010. Biography and History (Basingstoke, UK, and New York: Palgrave-Macmillan). Clark, Christopher, 2013. The Sleepwalkers. How Europe Went to War in 1914 (London: Penguin).

Corcuera, Javier, 2001. La patria de los vascos (Madrid: Taurus).

Elorza, Antonio, 2001. Un pueblo escogido (Barcelona: Crítica).

- (coord.), 2006. La historia de ETA. 2nd ed. (Madrid: Temas de Hoy).

Fraser, Ronald, 1979. Recuérdalo tu y recuérdalo a otros. Historia oral de la guerra civil española, vol. I. (Barcelona: Crítica).

Granja, José Luis de la, 2007. El oasis vasco. El nacimiento de Euskadi en la República y la Guerra Civil (Madrid: Tecnos).

-, 2008. Nacionalismo y II República en el País Vasco. Estatutos de autonomía, partidos y elecciones. Historia de Acción Nacionalista Vasca: 1930-1936 (Madrid: Siglo XXI).

Ibarzabal, Eugenio, 1977. Manuel de Irujo (San Sebastian: Erein).

Irujo, M., 1959. 'La república vasca', Euzko Deya de México, 223 (January).

-, 1960. 'Los últimos momentos de José Antonio. El primer presidente de Euzkadi', Alderdi, 157-58 (May).

Jáuregui, Gurutz, 1985. Ideología y estrategia política de ETA. Análisis de su evolución entre 1959 y 1968. 2nd ed. (Madrid: Siglo XXI).

Jiménez de Aberásturi, Juan Carlos (ed.), 1987. Los vascos en la II Guerra Mundial: El Consejo Nacional Vasco en Londres 1940-1944. (Recopilación documental.) (San Sebastian: Sociedad de Estudios Vascos/ Eusko Ikaskuntza).

Larronde, Jean-Claude, 1977. El nacionalismo vasco: su origen y su ideología en la obra de Sabino AranaGoiri (San Sebastian: Txertoa).

MacMillan, Margret, 2013. The War That Ended Peace. The Road to 1914 (New York: Random House).

McMeekin, Sean, 2013. July 1914: Countdown to War (New York: Basic Books).

Marx, Karl, 1999 [1852]. The Eighteenth Brumaire of Louis Napoleon. [Online edition.] Available at: www.marxists.org/archive/marx/works/1852/18th-brumaire [accessed 17 August 2016].

Mees, Ludger, 2006. El profeta pragmático. Aguirre, el primer lehendakari (1939-1960) (Irun: Alberdania).

—, 2012. 'Aguirre, entre carisma y mito’, in Ludger Mees and Xosé M. Núñez Seixas (eds), Nacidos para mandar. Liderazgo, política y poder. Perspectivas comparadas (Madrid: Tecnos), pp. 97-119.

Mees, Ludger, and Jesús Casquete, 2012. 'Telesforo Monzón', in Diccionario ilustrado de símbolos del nacionalismo vasco, by Santiago de Pablo, José Luis de la Granja, Ludger Mees and Jesús 
Casquete (Madrid: Tecnos), pp. 619-35.

Mees, Ludger, and José Luis de la Granja, 2012. 'Manuel Irujo', in Diccionario ilustrado de símbolos del nacionalismo vasco by Santiago de Pablo, José Luis de la Granja, Ludger Mees and Jesús Casquete (Madrid: Tecnos), pp. 563-78.

Mees, Ludger, José Luis de la Granja, Santiago de Pablo and José Antonio Rodríguez Ranz, 2014. La política como pasión. El lehendakari José Antonio Aguirre 1904-1960 (Madrid: Tecnos).

Münckler, Herfried, 2013. Der Grosse Krieg. Die Welt 1914-1918 (Berlin: Rowohlt).

O’Brien, Patrick K., 1998. 'Sketches from Life. Political Biography: A Polemical Review of the Genre', Biography, 21.1: 50-57.

Pablo, Santiago de, Ludger Mees and José Antonio Rodríguez Ranz, 1999. El péndulo patriótico. Historia del Partido Nacionalista Vasco. Vol. I: 1895-1936 (Barcelona: Crítica).

-, - and -, 2001. El péndulo patriótico. Historia del Partido Nacionalista Vasco. Vol. II: 1936-1979 (Barcelona: Crítica).

Rotberg, Robert I., 2010. 'Biography and Historiography: Mutual Evidentiary and Interdisciplinary Considerations', Journal of Interdisciplinary History, 40.3: 305-324.

Ugalde, Martín de, 1992. Manuel de Irujo. Un hombre leal a su tiempo (San Sebastian: Txertoa).

Vasconia, 2002. 'Jornadas Manuel de Irujo Ollo (1891-1981). En el 20. aniversario de su muerte', Vasconia, 32.

Vignaux, Paul, 1986. Manuel de Irujo. Ministre de la République dans la Guerre d’Espagne (Paris: Beauchesne). 
